\title{
OAXACA - BLINDER DECOMPOSITION EXTENDED FOR THE NON-LINEAR MODEL TO IDENTIFY THE OWNERSHIP GAP IN THE EXIT RATE
}

\author{
Nguyen Minh Ha, PhD, Ho Chi Minh City Open University
}

\begin{abstract}
S
The purpose of this research is to identify factors to explain the gap in exit rate between state and non-state firms in Vietnam. With a sample of 7,962 Vietnamese firms and using the Oaxaca-Blinder decomposition extended for non-linear models, the research finds out that a very large part of the ownership gap in exit rate between state and nonstate firms cannot be explained by the included covariates, but it is almost explained by the effects of differences in the coefficients of covariates. In particular, the differences in coefficients of covariates of initial assets, the industrial sector (mining, construction and manufacturing industries), and the service sector considerably increase the ownership gap in exit rate, but the difference in the coefficient of initial employment reduces the ownership gap in the exit rate. Moreover, differences in explanatory variables between state and non-state firms explain a very small part of the ownership gap in exit rate. This means that an estimate of the reduction in state and non-state firms' exit rates (resulting from giving non-state firms the same characteristics as state firms) is very small. The differences in coefficients have a much greater impact on differences in exit rates than characteristics that may be due to existing discrimination between state and non-state firms.
\end{abstract}

Keywords: Exit, Firms, Gap, Oaxaca-Blinder, Non-state, State

\section{Introduction}

In Vietnam, private firms are almost to medium and small enterprises until 2005 because they have the short time to accumulate the resource (i.e. they were established and developed from the Doi Moi policy). Meanwhile, state enterprises dominate in the economy and receive more preference. While in other countries, this is not the case, as the private sector is typically made up of private small, medium, and large enterprises. Thus, the majority of domestic private firms were small and medium sized new start-ups. Similarly, foreign firms were also newly set-up. Hence, due to various characteristics of state, and non-state ownerships, these two ownerships types may experience various probabilities of survival and exit. This research will engage in further study of the survival/exit rate of each firm ownership type and provide a comparison of survival/ exit rates between state and non-state firms. In so doing, answering to the following study questions:

Which factors can explain for the differences in exit rate between state and non-state firms?

And which factors are important to these differences?

Data for this research is the sample of 7,962 Vietnamese firms established prior to 2005. All firms are monitored until 2005, 
and the study period is from 2000 to 2005 . Firms in the sample can be also classified by ownership type. This study has applied the Oaxaca-Blinder decomposition extended for non-linear models for the analysis of identifying factors to explain for the exit rate gap between state and non-state firms in Vietnam.

The Oaxaca-Blinder decomposition has popularly been used in finding the discrimination in wage discrimination (Nielsen, 2000; Dorothe and Michael, 2001; Melly, 2005; Luiz; Elaine, 2007), in racial discrimination in health (Fournier, 2006; Darrell, 2006; Kirby,2006; Samuel, 2003), in earnings differential between urban residents and rural migrants (Deng, 2007), in households income (François, 2008) and etc.

The remainder of this study is organized as follows: Section 2 briefly reviews literature of Oaxaca-Blinder decomposition extended for the nonlinear. Next provides the Oaxaca-Blinder decomposition extended for the nonlinear version to identify factors which explain the differences in exit rate between state and non-state firms. Finally, conclusions and some policy implications are drawn from this analysis.

2. The Literature of the OaxacaBlinder decomposition extended for the non-linear model to identify the ownership gap in the exit rate

In order to identify factors that create differences in the survival/exit rates between state firms and non-state firms or other firms (foreign and domestic private firms), the Oaxaca-Blinder decomposition extended to the case of the binary logit and probit model is applied.

For a linear regression, according to the Oaxaca-Blinder decomposition model (1973), the dependent variable $(Y)$ takes the form of

$$
Y=X \beta+\varepsilon
$$

where $X$ represents vectors of observable characteristics, $\beta$ is vectors of coefficients, and $\varepsilon$ is the residual terms.

The group of state firms $(s)$ is $Y^{s}=$ $X^{s} \beta^{s}+\varepsilon^{s}$

and the group of non-state firms or other firms $(o)$ has $Y^{o}=X^{o} \beta^{o}+\varepsilon^{o}$

where $X^{s}$ and $X^{o}$ refer to firm characteristics of the sample of state and non-state owned firms, respectively. $\beta^{s}$ and $\beta^{o}$ are the parameters of estimations for the sample of state and non-state owned firms, respectively.

The mean values of the variables and estimated parameters in each group as $\bar{Y}^{s}=\bar{X}^{s} \hat{\beta^{s}}$ and $\bar{Y}^{o}=\bar{X}^{o} \hat{\beta}^{o}$, respectively.

The state and non-state ownership gap in the average value of the dependent variable, $Y$, can be written as

$$
\bar{Y}^{s}-Y^{o}=\bar{X}^{s} \hat{\beta^{s}}-\bar{X}^{o} \hat{\beta}^{o}
$$

After adding and subtracting $\bar{X}^{o} \hat{\beta}^{s}$, the gap becomes

$$
\bar{Y}^{s}-\bar{Y}^{o}=\left(\bar{X}^{s}-\bar{X}^{o}\right) \hat{\beta^{s}}-\bar{X}^{o}\left(\hat{\beta}^{s}-\hat{\beta}^{o}\right)
$$

The component $\left(\overline{\left.X^{s}-\bar{X}^{o}\right) \hat{\beta}^{s}}\right.$ is interpreted as the part of the gap in the value of dependent variables due to differences in observable (explained) average characteristics between state firms and non-state firms (foreign and domestic private firms). If the state firms and nonstate firms have the same levels of $X$, then this term would be 0 . Moreover, the other component, $\bar{X}^{o}\left(\hat{\beta}^{s}-\hat{\beta}^{o}\right)$, is the part attributed to differences in coefficient estimates (discrimination or unexplained). If coefficients are the same for state 
and non-state firms, then this term is 0 (the gap is due entirely to differences in characteristics).

An equally valid expression for equation (2.2) for the decomposition occurs when adding and subtracting $\bar{X}^{s} \hat{\beta}^{o}$ in the equation (2.1); the gap is written as:

$$
\bar{Y}^{s}-\bar{Y}^{o}=\left(\overline{X^{s}}-\bar{X}^{o}\right) \hat{\beta^{o}}-\bar{X}^{s}\left(\hat{\beta^{s}}-\hat{\beta}^{o}\right)
$$

The decomposition of the outcome variable similar to the equation (2.2) is not appropriate if the outcome is binary and the coefficients are from a logit or probit model. The coefficient estimates cannot be applied directly in the standard OaxacaBlinder decomposition equations.

Fairlie (1999, 2003, and 2005) and Yun (2000 and 2004) have extended the Oaxaca-Blinder decomposition for nonlinear models. The decomposition for a nonlinear equation, $Y=F(X \hat{\beta})$, can be
written as:

Or $\quad \overline{Y^{s}-Y^{o}}=$ characteristics effect + coefficient effect

$\bar{Y}^{s}-Y^{o}=\left[\bar{P}\left(X^{s} \beta^{s}\right)-\bar{P}\left(X^{o} \beta^{s}\right)\right]+\left[\bar{P}\left(X^{o} \beta^{s}\right)-\bar{P}\left(X^{o} \beta^{o}\right)\right]$

Where the binary dependent variable, $Y$, takes the value 1 if the firm exits, and 0 otherwise. $Y^{s}=\sum_{i=1}^{N^{s}} \frac{F\left(X_{i}^{s} \beta^{-}\right)}{N^{s}}$ , is the predicted probability of failure of state firms, and $Y^{o}=\sum_{i=1}^{N^{o}} \frac{F\left(X_{i}^{o} \beta^{o}\right)}{N^{o}}$, is the predicted probability of failure of nonstate firms. $N^{s}$ and $N^{o}$ are the number of state and non-state firms in the sample, respectively. $\quad \bar{P}$ represents the average predicted probability of the binary outcome (exit or survival), and $F$ is the cumulative distribution function from the logistic distribution.

The characteristic effect is due to the differences in predicted probabilities of exit when the firm characteristics of both state and non-state owned firms are used and the parameter vector is held constant. In other words, it represents the gap due to group differences in distributions of $X$.

The coefficient effect measures the differences in predicted probabilities of exit that result when the characteristics of non-state owned firms are held constant but the coefficient vectors of both state and non-state owned firms are used. In other words, The coefficient effect represents the part due to differences in the group processes determining levels of $Y$, and it is the part of the gap that is due to group differences in unobserved endowments (discrimination).

An equally valid expression to the equation (2.4) for the decomposition is:

$$
\bar{Y}^{s}-\bar{Y}^{o}=\left[\sum_{i=1}^{N^{s}} \frac{F\left(X_{i}^{s} \beta^{-}\right)}{N^{s}}-\sum_{i=1}^{N^{o}} \frac{F\left(X_{i}^{o} \beta^{o}\right)}{N^{o}}\right]+\left[\sum_{i=1}^{N^{s}} \frac{F\left(X_{i}^{s} \beta^{s}\right)}{N^{s}}-\sum_{i=1}^{N^{s}} \frac{F\left(X_{i}^{s} \beta^{o}\right)}{N^{s}}\right]
$$


In this equation (2.6), the state firm coefficient estimates, $\bar{\beta}^{\circ}$, are used as weights for the characteristic effects in the decomposition, and the non-state owned firm distribution of the independent variables, $X^{s}$, are used as weights for the coefficient effects.

Similarly, changing the reference group, an alternative expression for the decomposition is written as:

$$
\overline{Y^{o}}-Y^{s}=\left[\sum_{i=1}^{N^{o}} \frac{F\left(X_{i}^{o} \beta^{o}\right)}{N^{o}}-\sum_{i=1}^{N^{s}} \frac{F\left(X_{i}^{s} \beta^{o}\right)}{N^{s}}\right]+\left[\sum_{i=1}^{N^{s}} \frac{F\left(X_{i}^{s} \beta^{o}\right)}{N^{s}}-\sum_{i=1}^{N^{s}} \frac{F\left(X_{i}^{s} \beta^{s}\right)}{N^{s}}\right]
$$

The first term on the right hand side is (again) differences in the probability of exit between state and non-state owned firms that is due to differences in the covariates $X$. The second term is the part of the differences in the probability of exit

$$
\bar{Y}^{o}-Y^{s}=\left[\sum_{i=1}^{N^{o}} \frac{F\left(X_{i}^{o} \beta^{s}\right)}{N^{o}}-\sum_{i=1}^{N^{s}} \frac{F\left(X_{i}^{s} \beta^{s}\right)}{N^{s}}\right]+\left[\sum_{i=1}^{N^{o}} \frac{F\left(X_{i}^{o} \beta^{o}\right)}{N^{o}}-\sum_{i=1}^{N^{o}} \frac{F\left(X_{i}^{o} \beta^{s}\right)}{N^{o}}\right]
$$

The model in the equation (2.4) assumes that discrimination against nonstate firms, and that the exit rate of state firms is a base for a comparison of the two groups. In other words, it decomposes the difference in exit rate by comparing the difference between the exit rate of non-state firms based on their own exit structure and the exit of non-state firms based on the state exit structure. The characteristics effect represents the extent to which the differences in exit rate between state and non-state firms are that is due to differences in coefficients $(\beta)$ of both state and non-state owned firms.

An equally valid expression for the decomposition of the equation (2.7) is expressed as: accounted for by observed differences in firm characteristics. The residual effect measures the part due to differences in the regression coefficients and unobserved factors (due to discrimination).

The steps of the decomposition are given as follows:

First, a logit regression is estimated using the state and non-state samples ${ }^{1}$. Then, results of these coefficient estimates are used to calculate predicted probabilities evaluated at means of the independent variables:

${ }^{1}$ According to Guijarati (1995), the logit model is follows:

$P_{i}=E\left(Y=1 \mid X_{i}\right)=\beta_{\mathrm{o}}+\sum_{i=1}^{n} \beta_{i} X_{i}$

$P_{i}:$ is probability of exit $(Y=1) ; \beta_{1} \beta_{2}, \ldots \beta_{k}$ : are coefficients; Xi $(i=1, \ldots k)$ : Independent variables

Denote: $z=\beta_{0}+\beta_{1} X_{1}+\beta_{2} X_{2} \ldots+\beta_{k} X_{k}$

We have:

$$
P_{i}=\frac{e^{z}}{1+e^{z}}=\frac{1}{1+e^{-z}}=\frac{1}{1+e^{-\left(\beta_{0}+\beta_{1} X_{1}+\beta_{2} X_{2}+\ldots .+\beta_{k} X_{k}\right)}}
$$

and: $L_{i}=\boldsymbol{h}\left(\frac{P_{i}}{1-P_{i}}\right)=\beta_{0}+\beta_{1} X_{1}+\beta_{2} X_{2}+\ldots+\beta_{k} X_{k}$ 


$$
\bar{P}=\frac{1}{1+\exp (-\bar{X} \beta)}
$$

Next, the ownership gap in exit between state and non-state firms is calculated by the difference between the predicted probabilities between the two groups, based on the equation (2.5).

Finally, the counterfactuals are calculated to identify the contribution of each covariate to the state and non-state gap in exit. The contribution of each independent variable to the ownership gap is equal to the change in the mean predicted probability from replacing the nonstate firm distribution with the state firm distribution of that variable while holding the distribution of the other independent variable constant ${ }^{2}$. It follows that:

i) Characteristics effects: assuming that there are 3 variables $\left(X_{1}, X_{2}\right.$, and $\left.X_{3}\right)$.

The independent variables of $X_{1}$ to the gap can be expressed as:

$$
X_{1}: F\left(\alpha^{s}+\bar{X}_{1}^{o} \beta_{1}^{s}+\bar{X}_{2}^{s} \beta_{2}^{s}+\bar{X}_{3}^{s} \beta_{3}^{s}\right)-F\left(\alpha^{s}+\bar{X}_{1}^{s} \beta_{1}^{s}+\bar{X}_{2}^{s} \beta_{2}^{s}+\bar{X}_{3}^{s} \beta_{3}^{s}\right)
$$

Similarly, variables of $X_{2}$ and $X_{3}$ are written as:

$$
\begin{gathered}
X_{2}: F\left(\alpha^{s}+\bar{X}_{1}^{o} \beta_{1}^{s}+\bar{X}_{2}^{o} \beta_{2}^{s}+\bar{X}_{3}^{s} \beta_{3}^{s}\right)-F\left(\alpha^{s}+\bar{X}_{1}^{o} \beta_{1}^{s}+\bar{X}_{2}^{s} \beta_{2}^{s}+\bar{X}_{3}^{s} \beta_{3}^{s}\right) \\
X_{3}: F\left(\alpha^{s}+\bar{X}_{1}^{o} \beta_{1}^{s}+\bar{X}_{2}^{o} \beta_{2}^{s}+\bar{X}_{3}^{o} \beta_{3}^{s}\right)-F\left(\alpha^{s}+\bar{X}_{1}^{o} \beta_{1}^{s}+\bar{X}_{2}^{o} \beta_{2}^{s}+\bar{X}_{3}^{s} \beta_{3}^{s}\right)
\end{gathered}
$$

The sum of $X_{1}, X_{2}$, and $X_{3}$, the characteristic effect, is written as:

$$
F\left(\alpha^{s}+\bar{X}_{1}^{o} \beta_{1}^{s}+\bar{X}_{2}^{o} \beta_{2}^{s}+\bar{X}_{3}^{o} \beta_{3}^{s}\right)-F\left(\alpha^{s}+\bar{X}_{1}^{s} \beta_{1}^{s}+\bar{X}_{2}^{s} \beta_{2}^{s}+\bar{X}_{3}^{s} \beta_{3}^{s}\right)
$$

ii) Coefficient effects: for 3 variables $X_{1}, X_{2}$, and $X_{3}$,

The independent variables of $X_{1}$ to the gap can be expressed as:

$$
X_{1}: F\left(\alpha^{o}+\bar{X}_{1}^{o} \beta_{1}^{s}+\bar{X}_{2}^{o} \beta_{2}^{o}+\bar{X}_{3}^{o} \beta_{3}^{o}\right)-F\left(\alpha^{o}+\bar{X}_{1}^{o} \beta_{1}^{o}+\bar{X}_{2}^{o} \beta_{2}^{o}+\bar{X}_{3}^{o} \beta_{3}^{o}\right)
$$

Similarly, variables of $X_{2}$ and $X_{3}$ are given by:

$$
\begin{aligned}
& X_{2}: F\left(\alpha^{o}+\bar{X}_{1}^{o} \beta_{1}^{s}+\bar{X}_{2}^{o} \beta_{2}^{s}+\bar{X}_{3}^{o} \beta_{3}^{o}\right)-F\left(\alpha^{o}+\bar{X}_{1}^{o} \beta_{1}^{s}+\bar{X}_{2}^{o} \beta_{2}^{o}+\bar{X}_{3}^{o} \beta_{3}^{o}\right) \\
& X_{3}: F\left(\alpha^{o}+\bar{X}_{1}^{o} \beta_{1}^{s}+\bar{X}_{2}^{o} \beta_{2}^{s}+\bar{X}_{3}^{o} \beta_{3}^{s}\right)-F\left(\alpha^{o}+\bar{X}_{1}^{o} \beta_{1}^{s}+\bar{X}_{2}^{o} \beta_{2}^{s}+\bar{X}_{3}^{o} \beta_{3}^{o}\right)
\end{aligned}
$$

The sum of $X_{1}, X_{2}$ and $X_{3}$, the coefficient effect, is given by:

$$
F\left(\alpha^{o}+\bar{X}_{1}^{o} \beta_{1}^{s}+\bar{X}_{2}^{o} \beta_{2}^{s}+\bar{X}_{3}^{o} \beta_{3}^{s}\right)-F\left(\alpha^{o}+\bar{X}_{1}^{o} \beta_{1}^{o}+\bar{X}_{2}^{o} \beta_{2}^{o}+\bar{X}_{3}^{o} \beta_{3}^{o}\right)
$$

The equation (3.15) subtracts the equation (3.16); the ownership gap in exit is

$$
F\left(\alpha^{s}+\bar{X}_{1}^{s} \beta_{1}^{s}+\bar{X}_{2}^{s} \beta_{2}^{s}+\bar{X}_{3}^{s} \beta_{3}^{s}\right)-F\left(\alpha^{o}+\bar{X}_{1}^{o} \beta_{1}^{o}+\bar{X}_{2}^{o} \beta_{2}^{o}+\bar{X}_{3}^{o} \beta_{3}^{o}\right)
$$

\footnotetext{
${ }^{2}$ The non-linear case is different from the linear case; that is, the independent contributions of $X_{1}, X_{2}$ and $X_{3}$ depend on the value of the other variable. This implies that the choice of a variable as $X_{1}, X_{2}$ or $X_{3}$ (or the order of switching the distributions) is potentially important in calculating its contribution to the ownership gap in exit rate.
} 


\section{Study Data}

The main data for the study is from the firm-level database, which is the result of surveys conducted annually by the Vietnam General Statistical Office. The survey was first conducted in the year 2000 , and the data in question is recorded at the end of each calendar year (31 December). Such data from Vietnamese firms is currently available from the years 2000 to 2005 . Firms are drawn randomly from the total database, making the sample for this study a random one. The number of subjects for this research is 10,000 firms. After filtering unqualified firms according to the above criteria, the total number of subjects is 7,962 firms, which enter the sample from 2000-2005. All firms are monitored until 2005.

4. Results of the Oaxaca-Blinder decomposition extended for the non-linear model to identify the ownership gap in the exit rate Oaxaca-Blinder decomposition

\subsection{Description of variables used the Oaxaca-Blinder decomposition}

One dependent variable used in the logit regression is a status variable (Y) to distinguish failure or survival. It is the dummy variable capturing the occurrence of the hazard. $Y=1$ if the firm exits; otherwise, $\mathrm{Y}=0$.

There are explainatory variables in the logit model as well as in the OaxacaBlinder decomposition, follows:

The economic sector of the firm in operation: Firms in the agricultural sector (rural, agricultural, and fishery industries) are denoted by the variable AgriSector $=1$, 0 otherwise. Firms in the industrial sector (mining, construction, and manufacturing industries) are denoted by the variable InduSector $=1,0$ otherwise. Firms in the service sector (service industries) are denoted by ServSector $=1,0$ otherwise.
Firm size (Lnsize) is the logarithm of the number of employees in the firm at the start-up year. Similarly, the firm's assets (Lnassets) is the logarithm of the total asset of the firm at the start-up year. The firm's initial liability (Initialdebt) is the firm's debt at the start-up year. Capitalintensive (Capintensive) is the total capital per person employed by the firm at the start-up year.

The firm's productivity: Sales to employees in year $t-1$ (LagSaleslabor) is defined by the firm's gross sales over total employees in year $t-1$. Earnings before tax (EBT) to employees inyeart-1 (LagEBTlabor) is identified by dividing the firm's EBT by the total employees in year $t-1$

The previous growth in employment (LagGrowth): The firm's growth in employment is measured by the number of employees of the firm at year $t$ minus (-) the number of employees at year $t-1$, and then divided by the number of employees at year $t-1$.

The previous growth in assets (LagAssetgrowth): This variable is included into the model to consider the effect of previous growth in assets on firm survival. The firm's growth in assets is measured by the total assets of the firm at year $t$ minus (-) the total assets at year $t-1$, and then divided by the total assets at year $t-1$.

The firm's financial ratios and efficiency: Return to sales in year $t-1$ (LagROS) is calculated by dividing the earnings before tax by sales revenue in year $t-1$. Moreover, in this research, the return on assets in year $t$-1 (LagROA) ROA is calculated by dividing the EBT by the total assets of the firm in year $t-1$. Leverage in year $t-1$ (LagLeverage) is calculated by dividing debt (including short -, medium and long term debts) over the total assets in year $t-1$. 
4.2. Results of the Oaxaca-Blinder decomposition extended for the nonlinear model

As mentioned the steps of the decomposition, a logit regression is firstly estimated using the state and non-state samples. The logistic results of exit by state firms and non-state firms in Vietnam are shown in Appendix 1. Then, results of these coefficient estimates are used to calculate predicted probabilities evaluated at means of the independent variables

Next, the ownership gap in exit between state and non-state firms is calculated by the difference between the predicted probabilities between the two groups, based on the equation (2.5). Table 1 reports the predicted probabilities of exit rate between state and non-state firms; In Table 1, the average predicted probability of the state exit rate is 0.0225 , and the average predicted probability of the non-state exit rate is 0.0755 . Hence, the difference between state and not-state firms' exit rate is -0.0531 . This result illustrates that state firms experience a lower exit rate than non-state firms do. This is possibly explained by the fact that state firms are protected by the government and have more advantages and privileges than non-state firms have. The difference in exit rate between state and non-state firms are attributed to two effects: characteristic effects and coefficient effects.

Finally, the counterfactuals are calculated to identify the contribution of each covariate to the state and non-state gap in exit. The contribution of each independent variable to the ownership gap is equal to the change in the mean predicted probability from replacing the non-state firm distribution with the state firm distribution of that variable while holding the distribution of the other independent variable constant, based on the equations (2.10), (2.11) and (2.12).
Table 2 illustrates the contribution of each independent variable to the differences in exit rate between state and non-state firms in the characteristic effects and the coefficients effects (Table 2 is given by Appendixes 2 and 3).

In Table 2, The Chow test shows there is the difference in paremeters of two groups, and the decomposition analysis demonstrates that the characteristic effect explains only $1.49 \%$ of ownership difference of exit rate between state and non-state firms. This means that an estimate of the reduction in state and nonstate firms' exit rates resulting from giving non-state firms the same characteristics (the same distribution of all included variables) as state firms is $1.49 \%$. The characteristics of the industrial sector (firms in mining, construction, and manufacturing industries), initial assets, asset growth, and the return on sales (ROS) actually decrease the ownership gap in the explained effect (characteristics effects), with $2.17 \%, 1.64 \%, 0.84 \%$, and $2.05 \%$, respectively. However, differences between two groups in the service sector (firms in industries related to services), initial employment size, initial debt, initial capital intensity, productivity, employment growth, return on assets (ROA), and leverage actually increase the state and non-state gap in exit rates.

Most of this ownership difference in exitrate cannot be explained by the included covariates. The coefficient effect can show how much non-state firms would exit/ survive if they were treated like state firms in the market. In Table 2, the coefficient effect on the ownership gap in exit is very large (-0.0539). In particular, the effects of differences in coefficients of variables - such as initial assets, the industrial sector (firms in mining, construction and manufacturing industries), and the service sector (firms in industries related to services) - considerably increase the 
ownership gap Specifically, the difference in the coefficients which contributes to increasing the ownership gap in exit rate is the highest for the covariate of initial assets, with $43.87 \%$. The difference in two constants has the significant effect of widening the ownership gap in exit rate, with $41.72 \%$. Next, the effects of differences in coefficients of the industrial and service sectors increase the ownership gap in exit rate, with $10.79 \%$ and $11.59 \%$, respectively. However, the differences in coefficients of covariates to decrease the ownership gap are very small. The difference in the coefficient of initial employment to reduce the ownership gap is $4.57 \%$.

Hence, the difference in the state and non-state exit gap comes from the differences in coefficients which may arise for a variety of reasons:

Two different groups with the same characteristics experience different chances of business or technology.

Two groups might differ in terms of the participation behaviour of their owners or entrepreneurs.

A part of this difference is due to discrimination that might stem from the government's discrimination against non-state firms. As mentioned earlier, the Vietnamese government still retains the philosophy that state firms must take the dominant and decisive economic role. With this philosophy, compared to non-state firms, state firms take more preferences, privileges and support from the government; they are protected by the government; they keep sole positions in the economy such as important and profitable industries; their scopes of business are not limited, etc. Hence, there is an unequal business environment between state and non-state firms in Vietnam.

In sumamary, the results from this decomposition show that the differences in characteristics between state and non-state firms explain very little of the difference in exit rate. The differences in covariates that actually widen the gap in exit rate between state and non-state firms include the industrial sector, initial assets, asset growth, and return on sales. The differences in covariates that actually reduce the ownership gap in the exit rate include the service sector, initial employment, initial debt, initial capital intensity, productivity, employment growth, return on assets, and leverage. In fact, the ownership gap in the exit rate is almost explained by the effects of differences in the coefficients of covariates. In particular, differences in the coefficients of covariates of initial assets, the industrial sector (firms in mining, construction and manufacturing industries), and the service sector remarkably increase the ownership gap in exit rate, but the difference in the coefficient of initial employment reduces the ownership gap in the exit rate. The differences in the coefficients have a much greater effect on differences in the exit rate than characteristics that may be due to existing discrimination between state and non-state firms.

\section{Conclusion and policy implications}

\subsection{Conclusion}

In this study, the Oaxaca-Blinder decomposition extended for non-linear models are used to analyse the dataset of 7,962 Vietnamese firms in order to discover factors for explaining differences in the exit rate between state and non-state firms.

The most important finding for this study is from the Oaxaca-Blinder decomposition extended for the nonlinear version. That is, a very large part of the ownership gap in exit rate between state and non-state firms cannot be explained by the included covariates, but it is almost explained by the effects of differences in the coefficients of covariates. In 
particular, the differences in coefficients of covariates of initial assets, the industrial sector (firms in mining, construction and manufacturing industries), and the service sector considerably increase the ownership gap in exit rate, but the difference in the coefficient of initial employment reduces the ownership gap in the exit rate. Moreover, differences in explanatory variables between state and non-state firms explain a very small part of the ownership gap in exit rate. This means that an estimate of the reduction in state and non-state firms' exit rates (resulting from giving non-state firms the same characteristics as state firms) is very small. The differences in coefficients have a much greater impact on differences in exit rates than characteristics that may be due to existing discrimination between state and non-state firms (especially the government's discrimination against nonstate firms).

\subsection{Policy implications}

From the findings of the decomposition analysis above, some policies may be issued following: i) to decrease the support, preference, and privileges of state firms (compared to foreign and domestic private firms), ii) to stop discrimination in business among all types of firms and to generate a more equal business environment for all types of firms, iii) to allow domestic private and foreign firms access to some industries where state firms are exclusive at present. iv) to push the process of privatizing state firms so that domestic private and foreign ownerships can enter into these state firms, thus increasing survival prospects of privatized firms.

Table 1: The predicted probabilities of exit rate between state and non-state firms

\begin{tabular}{|c|c|c|c|c|}
\hline \multirow{2}{*}{ Variable } & \multicolumn{2}{|l|}{ State firms } & \multicolumn{2}{|c|}{ Non-state firms } \\
\hline & $\operatorname{Mean}\left(\bar{X}^{s}\right)$ & $-\bar{X}^{s} \beta^{s}$ & $\operatorname{Mean}\left(\bar{X}^{o}\right)$ & $-\bar{X}^{o} \beta^{o}$ \\
\hline InduSector & 0.2690 & 0.1264 & 0.3832 & 0.0951 \\
\hline ServSector & 0.7152 & 0.2644 & 0.6123 & 0.1275 \\
\hline Lnsize & 2.8061 & 0.0420 & 2.7855 & 0.0817 \\
\hline Lnassets & 7.2938 & 0.8003 & 7.6682 & 0.3824 \\
\hline Initialdebt & 13344.80 & 0.0278 & 6399.43 & 0.0207 \\
\hline Capintensive & 42.93 & -0.0070 & 72.20 & 0.0014 \\
\hline LagSaleslabor & 627.74 & 0.0047 & 606.75 & -0.0130 \\
\hline LagEBTlabor & 10.18 & 0.0156 & 4.6756 & 0.0081 \\
\hline LagGrowth & 0.1805 & -0.0022 & 0.2894 & 0.0276 \\
\hline LagGrowthSq & 1.3847 & -0.0010 & 2.6409 & -0.0149 \\
\hline LagAssetgrowth & 0.2656 & 0.0344 & 0.4282 & 0.0718 \\
\hline LagAssetgrowthSq & 2.2962 & -0.0135 & 3.7348 & -0.0206 \\
\hline LagROS (returns on sales) & 0.0427 & -0.0182 & -0.0808 & -0.0033 \\
\hline LagROA (returns on assets) & 0.0860 & 0.0404 & 0.0091 & 0.0066 \\
\hline LagLeverage & 0.0950 & -0.0320 & 0.1515 & -0.0309 \\
\hline Constant & & 2.4910 & & 1.7643 \\
\hline Total & & 3.7731 & & 2.5046 \\
\hline $\bar{P}$ & \multicolumn{2}{|l|}{0.0225} & \multicolumn{2}{|l|}{0.0755} \\
\hline Gap & \multicolumn{4}{|l|}{-0.0531} \\
\hline
\end{tabular}

Note: $\beta^{s}$ and $\beta^{o}$ are the coefficients of logistic estimations for the sample of state and non-state owned firms in Appendix 1, respectively. 
Table 2: Contribution of each variable to the ownership gap in characteristics effect and the coefficients effect ${ }^{(*)}$

\begin{tabular}{|c|c|c|c|c|c|c|}
\hline \multirow[b]{2}{*}{ Variable } & \multicolumn{3}{|c|}{ Characteristics effects } & \multicolumn{3}{|c|}{ Coefficient effects } \\
\hline & $\begin{array}{c}\bar{P}_{i}^{(a)} \\
\text { (counterfactuals) }\end{array}$ & $\bar{P}_{i}-\bar{P}_{i-1}^{-}$ & $\%$ to gap & $\begin{array}{c}\bar{P}_{i} \\
\text { (counterfactuals) }\end{array}$ & $\bar{P}_{i}-P_{i-1}^{-}$ & $\%$ to gap \\
\hline InduSector & 0.0213 & -0.00115 & $-2.17 \%$ & 0.0698 & -0.0057 & $10.79 \%$ \\
\hline ServSector & 0.0221 & 0.00081 & $1.52 \%$ & 0.0637 & -0.0061 & $11.59 \%$ \\
\hline Lnsize & 0.0221 & 0.00001 & $0.01 \%$ & 0.0661 & 0.0024 & $-4.57 \%$ \\
\hline Lnassets & 0.0213 & -0.00087 & $-1.64 \%$ & 0.0428 & -0.0233 & $43.87 \%$ \\
\hline Initialdebt & 0.0216 & 0.00030 & $0.57 \%$ & 0.0431 & 0.0003 & $-0.58 \%$ \\
\hline Capintensive & 0.0217 & 0.00010 & $0.19 \%$ & 0.0437 & 0.0005 & $-1.03 \%$ \\
\hline LagSaleslabor & 0.0217 & 0.000003 & $0.01 \%$ & 0.0429 & -0.0007 & $1.36 \%$ \\
\hline LagEBTlabor & 0.0218 & 0.00018 & $0.34 \%$ & 0.0430 & 0.0000 & $-0.08 \%$ \\
\hline LagGrowth & 0.0219 & 0.00003 & $0.05 \%$ & 0.0443 & 0.0013 & $-2.44 \%$ \\
\hline LagGrowthSq & 0.0219 & 0.00002 & $0.04 \%$ & 0.0437 & -0.0005 & $1.03 \%$ \\
\hline LagAssetgrowth & 0.0214 & -0.00045 & $-0.84 \%$ & 0.0444 & 0.0007 & $-1.29 \%$ \\
\hline LagAssetgrowthSq & 0.0216 & 0.00018 & $0.34 \%$ & 0.0445 & 0.0001 & $-0.11 \%$ \\
\hline LagROS & 0.0205 & -0.00109 & $-2.05 \%$ & 0.0429 & -0.0016 & $2.97 \%$ \\
\hline LagROA & 0.0213 & 0.00074 & $1.39 \%$ & 0.0430 & 0.0001 & $-0.18 \%$ \\
\hline LagLeverage & 0.0217 & 0.00040 & $0.75 \%$ & 0.0438 & 0.0008 & $-1.57 \%$ \\
\hline Constant & 0.0217 & 0.00000 & $0.00 \%$ & 0.0217 & -0.0221 & $41.72 \%$ \\
\hline Total & & $-0.0008^{(b)}$ & $-1.49 \%$ & & $-0.0539^{(\mathrm{c})}$ & $101.49 \%$ \\
\hline Gap & & & $-0.0531^{(\mathrm{d})}$ & $(100.00 \%)$ & & \\
\hline$F(47,22062)$ & & & & & & \\
\hline Prob $>$ F & & & & & & \\
\hline
\end{tabular}

Note: ${ }^{(*)}$ Results from this table is from appendix 2 and 3

$$
\begin{aligned}
& \text { (a): } \bar{P}\left(X^{o} \beta^{s}\right) ;{ }^{(b)}: \bar{P}\left(X^{o} \beta^{s}\right)-\bar{P}\left(X^{s} \beta^{s}\right) ;{ }^{(c)}: \bar{P}\left(X^{o} \beta^{s}\right)-\bar{P}\left(X^{o} \beta^{o}\right) \\
& (d)=(c)-(b)=\left[\bar{P}\left(X^{s} \beta^{s}\right)-\bar{P}\left(X^{o} \beta^{s}\right)\right]+\left[\bar{P}\left(X^{o} \beta^{s}\right)-\bar{P}\left(X^{o} \beta^{o}\right)\right]
\end{aligned}
$$




\section{REFERENCES}

Blinder, A. S. (1973), 'Wage Discrimination: Reduced Form and Structural Estimates', The Journal of Human Resources, Vol. 8, No. 4, pp. 436-455

Darrell J. Gaskin, Becky A. Briesacher, M. Rhonda Limcangco, and Betsy L. Brigantti (2006), "Exploring racial and ethnic disparities in prescription drug spending and use among Medicare beneficiaries" The American journal of geriatric pharmacotherapy 4.2 (2006).

Deng, Q. (2007), "Earnings Differential between Urban Residents and Rural Migrants:Evidence from Oaxaca-Blinder and Quantile Regression Decompositions". Chinese Journal of Population Science. 2007-2

Dorothe, B. , and Michael. G. (2001), "The unequal distribution of unequal pay - An empirical analysis of the gender wage gap in Switzerland". Empirical Economics. May 2001, Vol.26, Iss.2, pp 407-427

Fairlie, R. W. (1999), 'The Absence of the African-American Owned Business: An Analysis of the Dynamics of Self-Employment', Journal of Labour Economics, Vol. 17. No. 1, pp.80-108

Fairlie, R. W. (2005), 'An Extension of the Blinder-Oaxaca decomposition technique to Logit and Probit Models', Journal of Economic and Social Measurement 30(2005), 305-316.

Fournier, M. (2006), "Exploiting information from path dependency in Oaxaca-Blinder decomposition procedures". Applied Economics Letters. Vol 12, Iss. 11, 2005

François, B., Francisco, H. G. F, and Phillippe G. L. (2008), "Beyond Oaxaca-Blinder: Accounting for differences in household income distributions". The Journal of Economic Inequality. June 2008, Volume 6, Iss. 2, pp 117-148

Kirby, J. B., Taliaferro, G., Zuvekas, S. H. ( 2006), "Explaining Racial and Ethnic Disparities in Health Care”. Medical Care. May 2006, Vol. 44, Iss.5 - pp I-64-I-72

Luiz, G. S. and Elaine, T. P. (2007), "Using normalized equations to solve the indetermination problem in the Oaxaca-Blinder decomposition: an application to the gender wage gap in Brazil". Rev. Bras. Econ. vol.61 no.4

Melly, B. (2005), "Decomposition of differences in distribution using quantile regression”. Labour Economics. Vol 12, Iss 4, pp. 577-590

Nielsen, H. S. (2000), "Wage discrimination in Zambia: an extension of the OaxacaBlinder decomposition”. Applied Economics Letters. Vol.7, Iss.6, 2000

Oaxaca, R. (1973), 'Male-Female Wage Differentials in Urban Labor Markets', International Economic Review, Vol. 14, No. 3, pp. 693-709

Samuel H. Z. and Gregg S. T. (2003), "Pathways To Access: Health Insurance, The Health Care Delivery System, And Racial/Ethnic Disparities, 1996-1999”. Health Affairs. March 2003, Vol. 22, No.2, pp.139-153

Yun, M. S. (2000), 'Decomposition Analysis for a Binary Choice Model', IZA Discussion Paper No. 145, April 2000.

Yun, M. S. (2004), 'Decomposing Differences in the First Comment', Economics Letters 82 (2004) $275-280$. 
Appendix 1: The Logistic results of exit rates by state firms and non-state firms in Vietnam ${ }^{(*)}$

\begin{tabular}{|c|c|c|}
\hline \multirow{2}{*}{ Variables } & \multicolumn{2}{|c|}{ Parameter estimates (Exit) } \\
\hline & State firms & Non-state firms \\
\hline Constant & $\begin{array}{c}-2.491 * * \\
(1.144)\end{array}$ & $\begin{array}{l}-1.764 \\
(1.117)\end{array}$ \\
\hline InduSector & $\begin{array}{l}-0.470 \\
(0.294)\end{array}$ & $\begin{array}{c}-0.248 \\
(0.379)\end{array}$ \\
\hline ServSector & $\begin{array}{l}-0.370 \\
(0.292) \\
\end{array}$ & $\begin{array}{c}-0.208 \\
(0.378)\end{array}$ \\
\hline Lnsize & $\begin{array}{c}-0.015 \\
(0.051) \\
\end{array}$ & $\begin{array}{c}-0.029 \\
(0.031)\end{array}$ \\
\hline Lnassets & $\begin{array}{c}-0.110^{* * *} \\
(0.044)\end{array}$ & $\begin{array}{c}-0.050 * * \\
(0.025)\end{array}$ \\
\hline Initialdebt & $\begin{array}{c}-2.08 \mathrm{e}-06 \\
(1.86 \mathrm{e}-06) \\
\end{array}$ & $\begin{array}{l}-3.24 \mathrm{e}-06 \\
(2.08 \mathrm{e}-06)\end{array}$ \\
\hline Capintensive & $\begin{array}{c}0.0002 \\
(0.0004)\end{array}$ & $\begin{array}{c}-1.9 \mathrm{e}-05 \\
(0.000148)\end{array}$ \\
\hline LagSaleslabor & $\begin{array}{c}-7.41 \mathrm{e}-06 \\
(3.64 \mathrm{e}-05)\end{array}$ & $\begin{array}{c}2.14 \mathrm{e}-05 \\
(2.01 \mathrm{e}-05)\end{array}$ \\
\hline LagEBTlabor & $\begin{array}{l}-0.002 \\
(0.002)\end{array}$ & $\begin{array}{c}-0.002 * * \\
(0.001)\end{array}$ \\
\hline LagGrowth & $\begin{array}{c}0.012 \\
(0.069)\end{array}$ & $\begin{array}{c}-0.095^{* * *} \\
(0.034)\end{array}$ \\
\hline LagGrowthSq & $\begin{array}{c}0.001 \\
(0.004)\end{array}$ & $\begin{array}{c}0.006 * * * \\
(0.002)\end{array}$ \\
\hline LagAssetgrowth & $\begin{array}{c}-0.130 * * \\
(0.060)\end{array}$ & $\begin{array}{c}-0.168 * * * \\
(0.033)\end{array}$ \\
\hline LagAssetgrowthSq & $\begin{array}{c}0.006^{* *} \\
(0.003)\end{array}$ & $\begin{array}{c}0.006 * * * \\
(0.002)\end{array}$ \\
\hline LagROS (returns on sales) & $\begin{array}{l}0.427 * \\
(0.244)\end{array}$ & $\begin{array}{l}-0.041 \\
(0.036)\end{array}$ \\
\hline LagROA (returns on assets) & $\begin{array}{c}-0.470 * * \\
(0.243)\end{array}$ & $\begin{array}{c}-0.723 * * * \\
(0.149)\end{array}$ \\
\hline LagLeverage & $\begin{array}{c}0.337 * * \\
(0.160) \\
\end{array}$ & $\begin{array}{c}0.204 * * * \\
(0.086)\end{array}$ \\
\hline Age dummies & Yes & Yes \\
\hline Log Likelihood & $-2,188.7$ & $-5,296.5$ \\
\hline LR (p value) & 0.000 & 0.000 \\
\hline Number of firms $(\mathrm{N})$ & 2,401 & 5,617 \\
\hline Observations & 5,507 & 16,602 \\
\hline
\end{tabular}

Note: $\left.{ }^{*}\right): Y=F(I n d u S e c t o r$, ServSector, Lnsize, Lnassets, Initialdebt, Capintensive, LagSaleslabor, LagEBTlabor, LagGrowth, LagGrowthSq, LagAssetgrowth, LagAssetgrowthSq, LagROS, LagROA, LagLeverage, Age dummies)

The reference group for dummies is AgriSector

Std. Error-values are in parentheses. $* * *$ is significant at $1 \%, * *$ is significant at $5 \%$, and $*$ is significant at $10 \%$. 


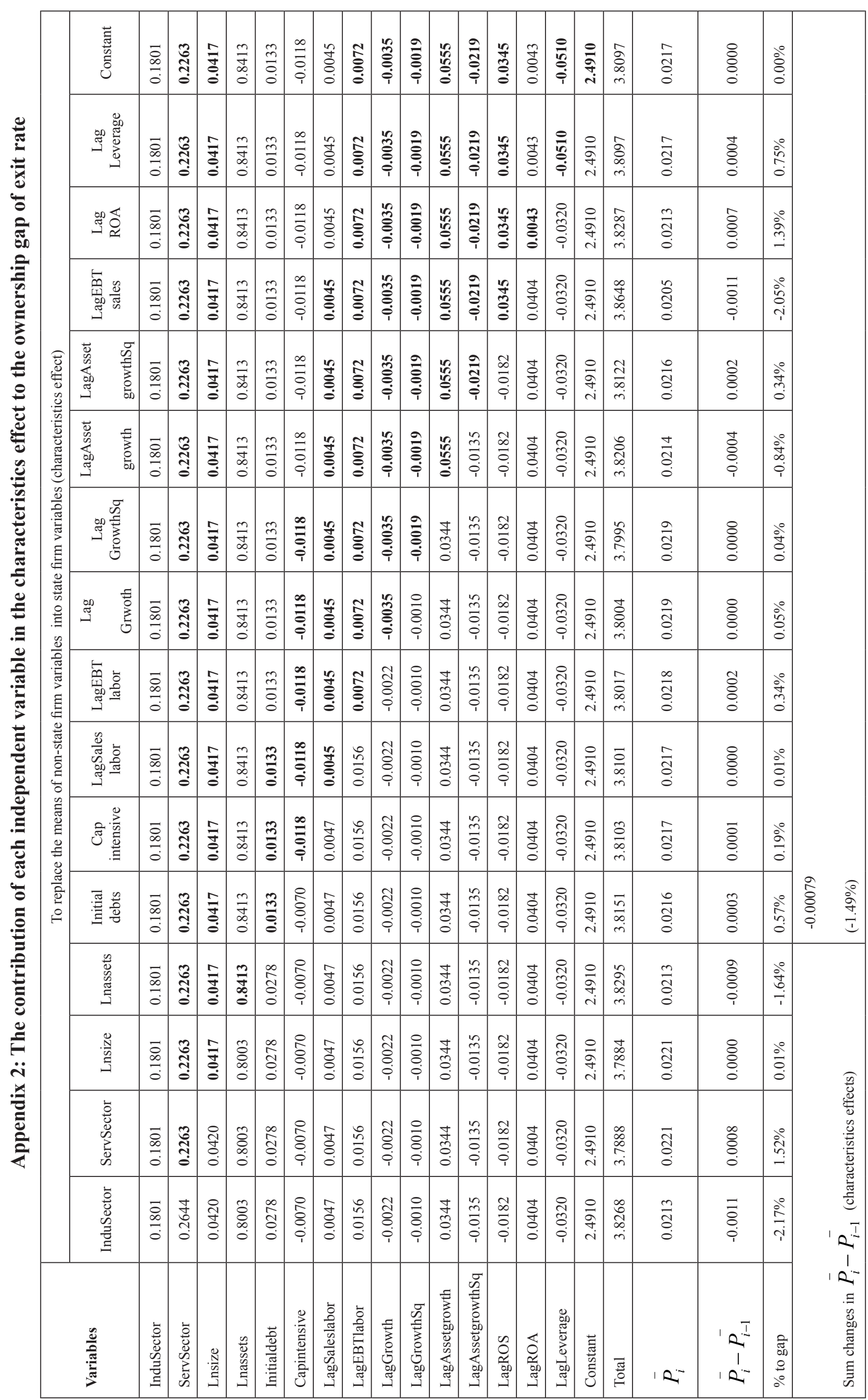




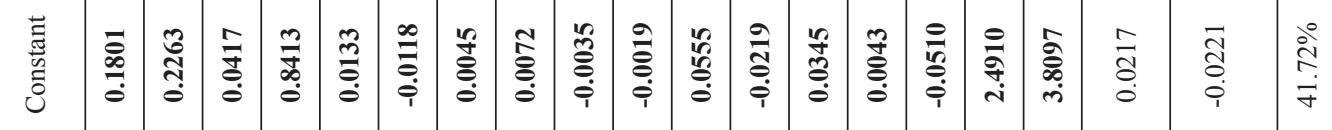

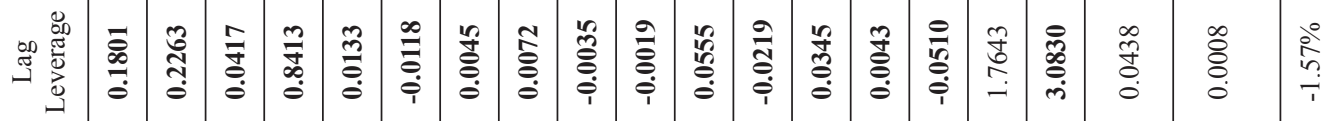

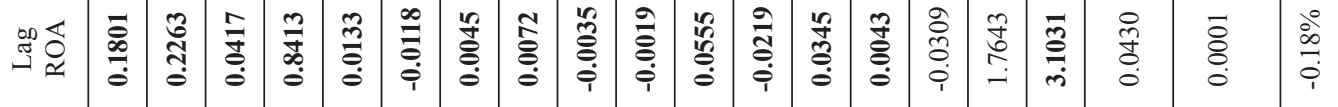

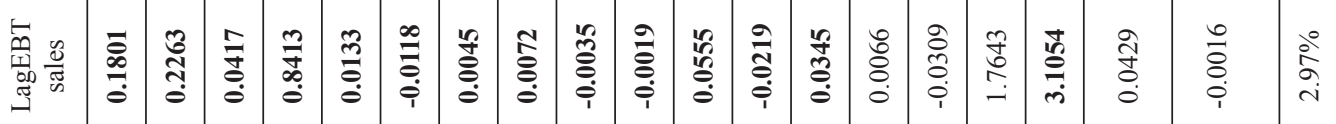

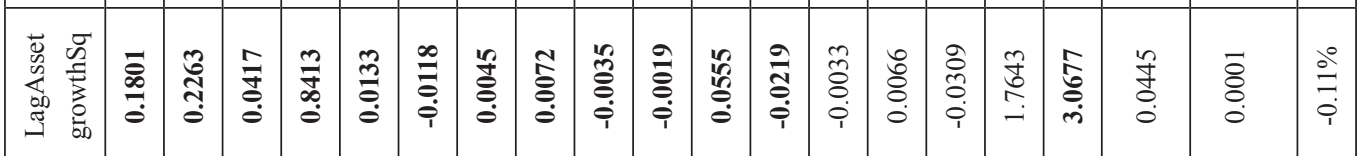

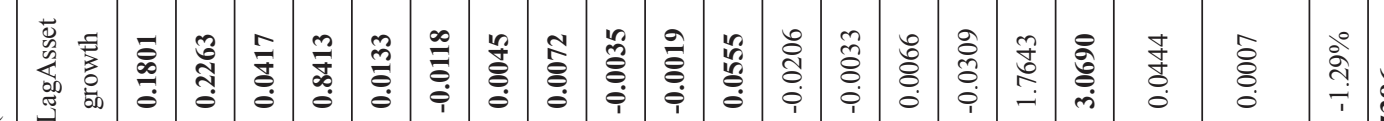

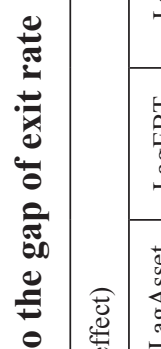

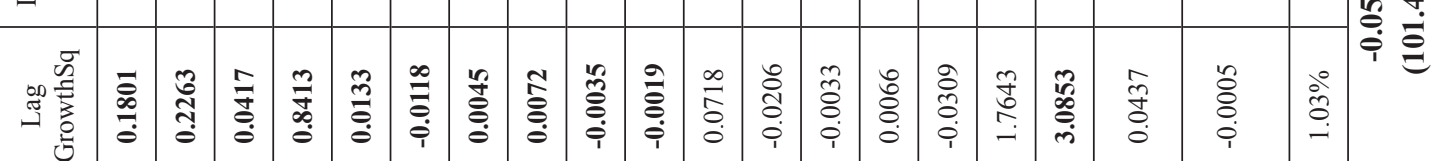

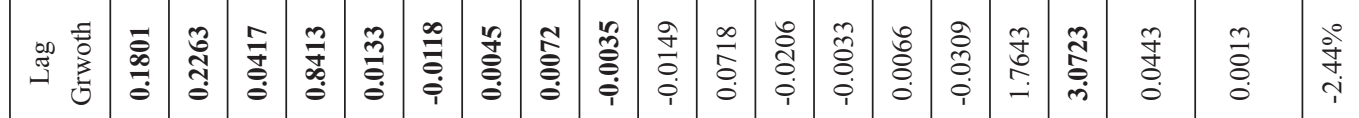

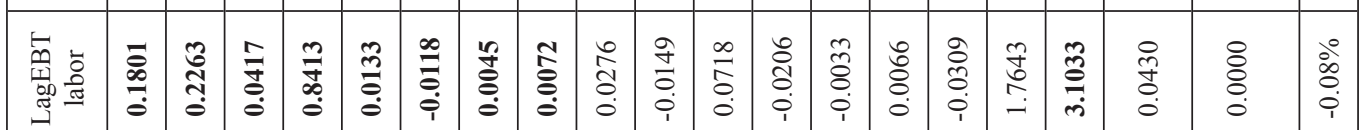

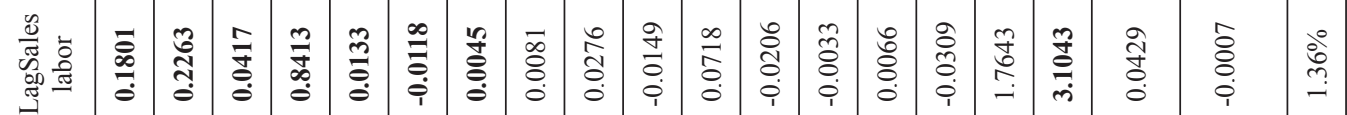

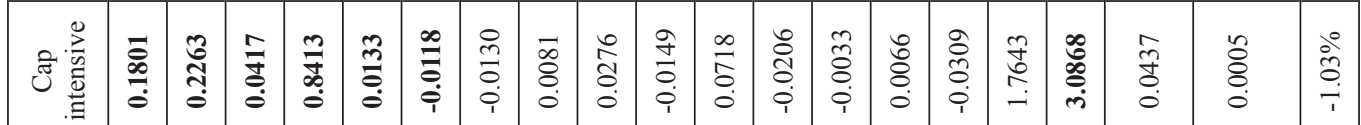

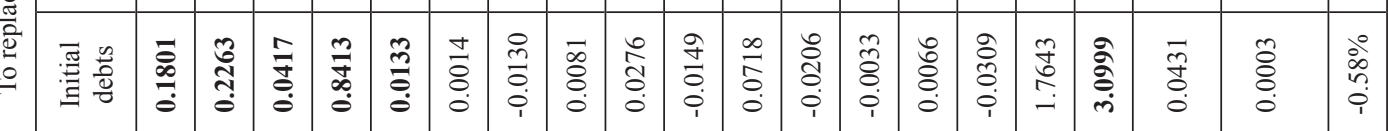

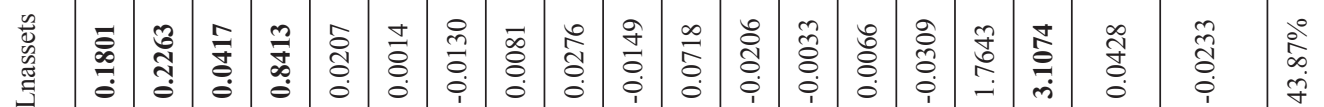

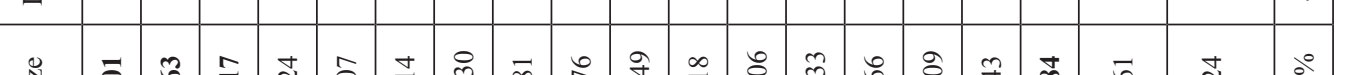

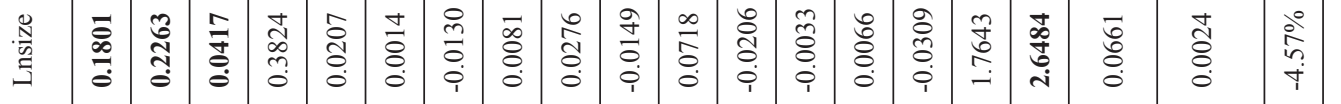

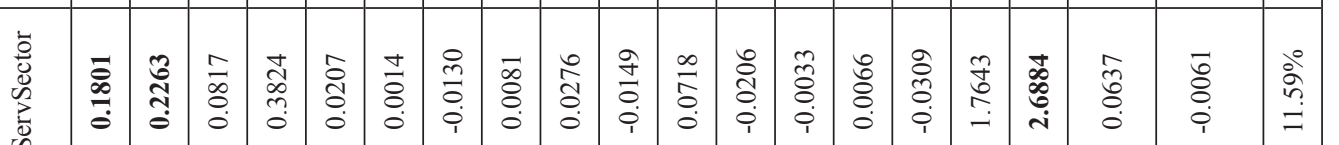

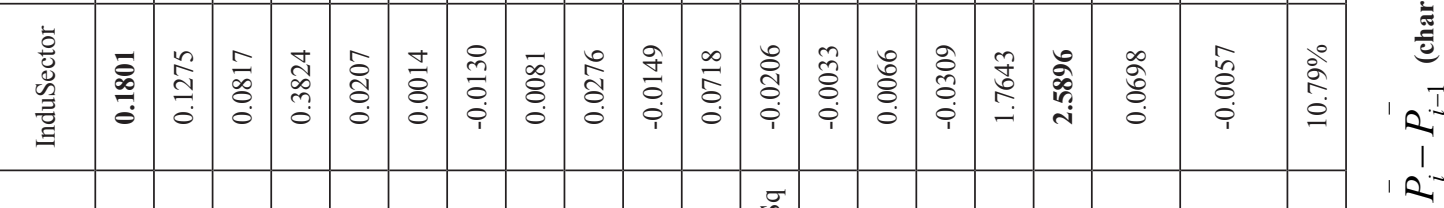

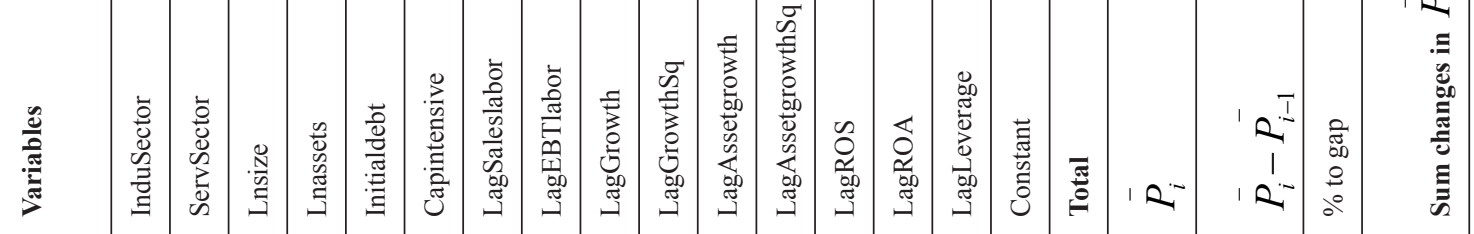




\begin{tabular}{|c|c|c|c|c|c|c|c|c|c|c|c|c|c|c|c|c|c|c|c|c|c|c|c|}
\hline \multirow{16}{*}{ 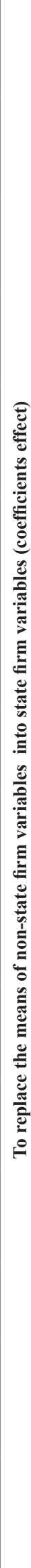 } & 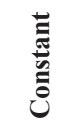 & $\frac{\overline{0}}{0}$ & ֶָ. & $\stackrel{\Xi}{\sigma}$ & $\begin{array}{l}\stackrel{m}{\sigma} \\
\stackrel{\alpha}{\alpha} \\
\stackrel{0}{0}\end{array}$ & $\stackrel{m}{\stackrel{3}{0}}$ & $\begin{array}{l}\infty \\
\bar{\Xi} \\
\bar{i}\end{array}$ & 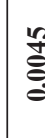 & $\hat{E}$ & $\tilde{\Xi}$ & & & & हू & 先 & 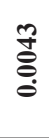 & $\begin{array}{l}\stackrel{0}{10} \\
\stackrel{10}{0} \\
\stackrel{1}{1}\end{array}$ & 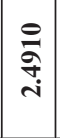 & $\left|\begin{array}{|c}\hat{\hat{े}} \\
\hat{\sigma} \\
\dot{j}\end{array}\right|$ & $\begin{array}{l}\stackrel{\widetilde{\sigma}}{0} \\
\dot{0}\end{array}$ & $\begin{array}{l}\overrightarrow{\widetilde{J}} \\
\text { Oे }\end{array}$ & 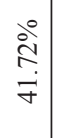 & \multirow{12}{*}{ 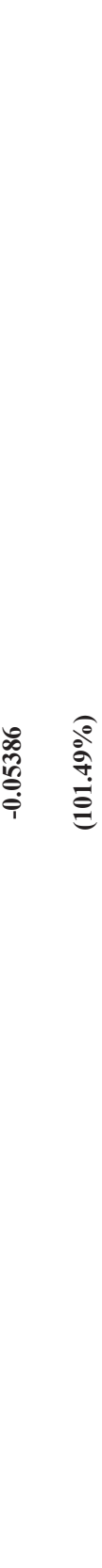 } \\
\hline & لَّ & 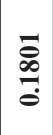 & 芯 & 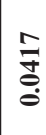 & 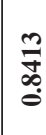 & @ٕ & 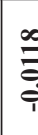 & $\stackrel{\text { Lf }}{\stackrel{0}{0}}$ & $\hat{g}$ & है & . & & סृ & ֶָ. & 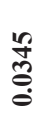 & 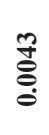 & $\begin{array}{l}\stackrel{0}{0} \\
\stackrel{0}{0} \\
\stackrel{i}{0}\end{array}$ & $\mid \begin{array}{c}\mathfrak{f} \\
\stackrel{0}{0} \\
-\end{array}$ & 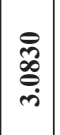 & 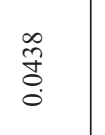 & \begin{tabular}{l}
$\infty$ \\
\multirow{0}{0}{} \\
0 \\
0
\end{tabular} & 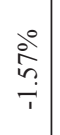 & \\
\hline & 品 & 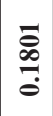 & 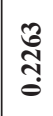 & 音 & 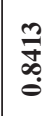 & 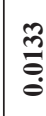 & $\begin{array}{l}\text { E } \\
\\
\end{array}$ & : & $\hat{g}$ & ڤ્ٌ & 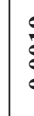 & & . & 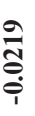 & 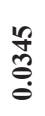 & 第 & $\begin{array}{l}\text { के } \\
\text { क्. } \\
\text { î }\end{array}$ & 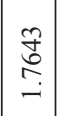 & $\mid \begin{array}{c}\overrightarrow{6} \\
\stackrel{m}{m}\end{array}$ & 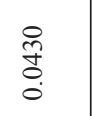 & $\begin{array}{l}\overline{0} \\
\text { ठ̊. }\end{array}$ & $\begin{array}{l}\stackrel{0}{\circ} \\
\stackrel{0}{\circ} \\
\dot{i}\end{array}$ & \\
\hline & 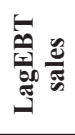 & 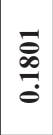 & đֶ. & 章 & 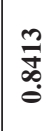 & $\stackrel{m}{3}$ & 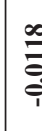 & 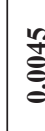 & $\hat{E}$ & है & 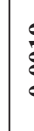 & 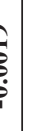 & $\begin{array}{l}6 \\
6 \\
6 \\
0 \\
0\end{array}$ & 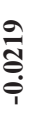 & 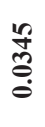 & $\begin{array}{l}0 \\
\vdots \\
0 \\
0\end{array}$ & $\begin{array}{l}\text { वे } \\
\text { है. } \\
\text { i. }\end{array}$ & $\mid \begin{array}{c}\mathfrak{q} \\
\stackrel{f}{:} \\
-\end{array}$ & 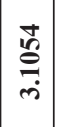 & సे & $\begin{array}{l}\stackrel{0}{\circ} \\
\stackrel{0}{0}\end{array}$ & 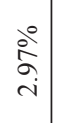 & \\
\hline & 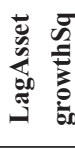 & 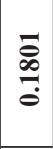 & 芯 & $\stackrel{\overrightarrow{7}}{\stackrel{5}{0}}$ & $\begin{array}{l}\stackrel{m}{\sigma} \\
\stackrel{0}{\alpha} \\
\stackrel{0}{0}\end{array}$ & $\stackrel{m}{\stackrel{3}{0}}$ & 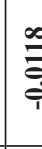 & $\stackrel{\text { If }}{\stackrel{0}{0}}$ & $\hat{E}$ & ڤ̆ & & 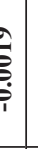 & 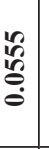 & 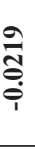 & 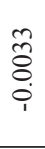 & $\begin{array}{l}\text { ठ } \\
\vdots \\
0 \\
0\end{array}$ & $\begin{array}{l}\text { वे } \\
\text { : } \\
\text { î. }\end{array}$ & 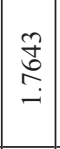 & 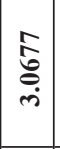 & \begin{tabular}{l}
$\frac{n}{8}$ \\
\multirow{0}{0}{} \\
0
\end{tabular} & 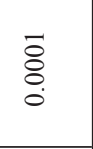 & $\begin{array}{l}\stackrel{0}{二} \\
\stackrel{0}{\dagger}\end{array}$ & \\
\hline & 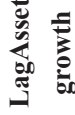 & $\frac{\overline{0}}{0}$ & ڤ్ర & $\stackrel{F}{\sigma}$ & 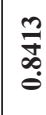 & ֻٕ & $\begin{array}{l}\infty \\
\\
\\
\end{array}$ & $\stackrel{n}{ \pm}$ & $\hat{E}$ & שै & & & 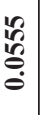 & 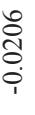 & 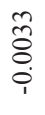 & $\begin{array}{l}\text { : } \\
\vdots \\
0\end{array}$ & $\begin{array}{l}\text { वे } \\
\text { हैं } \\
\text { i }\end{array}$ & $\begin{array}{c}\stackrel{?}{d} \\
\stackrel{-}{-}\end{array}$ & 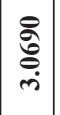 & $\underset{0}{\stackrel{J}{0}}$ & 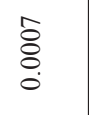 & $\begin{array}{l}\text { 今े } \\
\stackrel{\text { ch }}{1}\end{array}$ & \\
\hline & Uू. & $\stackrel{\overline{0}}{\stackrel{0}{0}}$ & 芯 & 章 & $\begin{array}{l}\stackrel{m}{\sigma} \\
\stackrel{\sigma}{\circ} \\
\stackrel{0}{0}\end{array}$ & $\stackrel{m}{0}$ & 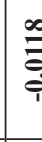 & If & $\hat{g}$ & 气̆ & 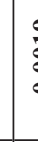 & & 年 & 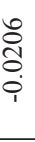 & $\begin{array}{l}\text { ले } \\
\hat{o} \\
\dot{i}\end{array}$ & $\begin{array}{l}0 \\
\vdots \\
0 \\
0\end{array}$ & $\begin{array}{l}\text { Oे } \\
\text { Oo } \\
\text { i. }\end{array}$ & $\mid \begin{array}{c}0 \\
\stackrel{f}{0} \\
\stackrel{i}{-}\end{array}$ & $\mid \begin{array}{c}0 \\
0 \\
0 \\
0 \\
\dot{\infty}\end{array}$ & $\begin{array}{l}\hat{\tilde{g}} \\
0 \\
0\end{array}$ & 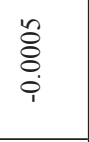 & $\stackrel{\text { ळे }}{\stackrel{一}{\circ}}$ & \\
\hline & ثِ & $\frac{\overline{0}}{\stackrel{\infty}{0}}$ & ڤ્ర & $\stackrel{5}{\sigma}$ & 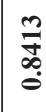 & $\stackrel{m}{3}$ & $\begin{array}{l}\infty \\
\\
\bar{\Xi}\end{array}$ & 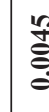 & $\hat{E}$ & ש̂́ & 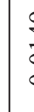 & to & $\frac{\infty}{\sigma_{0}^{\circ}}$ & 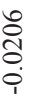 & 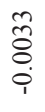 & $\begin{array}{l}0 \\
0 \\
8 \\
0 \\
0\end{array}$ & $\begin{array}{l}\text { oे } \\
\text { o. } \\
\text { i. }\end{array}$ & 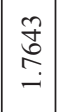 & 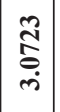 & $\underset{8}{\stackrel{O}{8}}$ & $\stackrel{m}{\stackrel{m}{0}}$ & $\begin{array}{c}\stackrel{\circ}{+} \\
\stackrel{+}{+} \\
i\end{array}$ & \\
\hline & 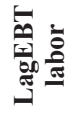 & 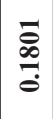 & 芯 & 章 & 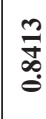 & @ٕ & 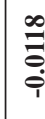 & $\stackrel{\text { If }}{\stackrel{5}{0}}$ & $\hat{E}$ & 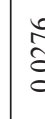 & 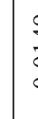 & & $\begin{array}{l}\infty \\
\overbrace{0}^{\circ} \\
\end{array}$ & 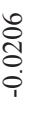 & 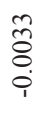 & $\begin{array}{l}0 \\
0 \\
\vdots \\
0 \\
0\end{array}$ & $\begin{array}{l}\text { के } \\
\text { o. } \\
\text { i }\end{array}$ & $\mid \begin{array}{c}\stackrel{?}{0} \\
\stackrel{-}{-}\end{array}$ & $\frac{\tilde{m}}{\stackrel{\tilde{s}}{\oplus}}$ & 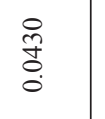 & 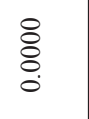 & $\begin{array}{l}0 \\
\stackrel{0}{0} \\
0 \\
\dot{0} \\
1\end{array}$ & \\
\hline & 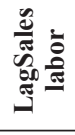 & $\mid$\begin{tabular}{c}
$\overline{0}$ \\
\hdashline \\
\\
\end{tabular} & 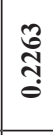 & $\stackrel{亏}{\sigma}$ & 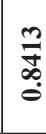 & ֻٕ: & $\stackrel{\infty}{\infty}$ & 点 & $\bar{a}$ & å & 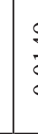 & & 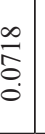 & 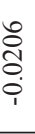 & $\begin{array}{l}\text { ⿵人 } \\
\stackrel{\delta}{0} \\
\dot{i}\end{array}$ & $\begin{array}{l}0 \\
0 \\
0 \\
0 \\
0\end{array}$ & $\begin{array}{l}\text { oे } \\
\text { : } \\
\text { iे }\end{array}$ & $\begin{array}{c}\text { fôn } \\
\stackrel{0}{-}\end{array}$ & 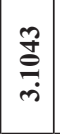 & సे & $\begin{array}{l}\hat{\Xi} \\
\vdots \\
\\
i\end{array}$ & 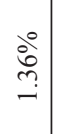 & \\
\hline & Uี & 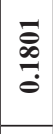 & گુ & $\stackrel{\sigma}{\sigma}$ & 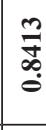 & @ٕ & & $\begin{array}{l}\text { ⿳亠丷厂 } \\
\text { a } \\
\text { i }\end{array}$ & a & a & 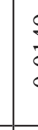 & t: & \begin{tabular}{l}
$\infty$ \\
\multirow{2}{\infty}{} \\
0 \\
0 \\
\end{tabular} & 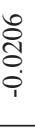 & $\begin{array}{l}\text { ⿵人丶 } \\
\hat{o} \\
\dot{i}\end{array}$ & 递 & $\begin{array}{l}\text { oे } \\
\text { o. } \\
\text { i }\end{array}$ & 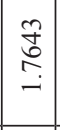 & $\mid \begin{array}{c}\infty \\
\stackrel{0}{0} \\
\stackrel{\infty}{\infty} \\
\dot{m}\end{array}$ & $\begin{array}{l}\hat{\tilde{O}} \\
\dot{0} \\
\dot{0}\end{array}$ & $\begin{array}{l}\text { o̊ } \\
\vdots \\
0\end{array}$ & 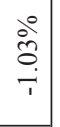 & \\
\hline & 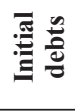 & $\underset{\bar{\infty}}{\stackrel{0}{0}}$ & 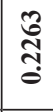 & $\stackrel{\vec{f}}{\stackrel{\Xi}{0}}$ & 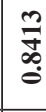 & 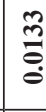 & $\stackrel{+}{8}$ & 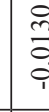 & वे & $\grave{a}$ & 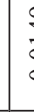 & & $\begin{array}{l}\infty \\
\\
0 \\
0\end{array}$ & 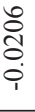 & 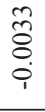 & $\begin{array}{l}0 \\
\vdots \\
8 \\
0\end{array}$ & $\begin{array}{l}\text { के } \\
\text { ¿ें } \\
\text { i }\end{array}$ & 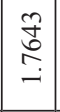 & $\mid$\begin{tabular}{|l}
$\hat{\sigma}$ \\
$\stackrel{\vec{\sigma}}{\dot{m}}$
\end{tabular} & 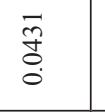 & 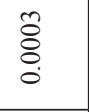 & $\begin{array}{c}0 \\
\infty \\
0 \\
i \\
i \\
1\end{array}$ & \\
\hline & 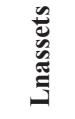 & $\stackrel{\overline{0}}{\overline{0}}$ & 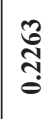 & 音 & 疍 & 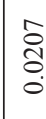 & 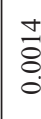 & $\begin{array}{l}\text { ले } \\
\text { a } \\
\text { i }\end{array}$ & $\bar{a}$ & 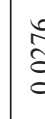 & 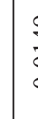 & & 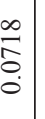 & & $\begin{array}{l}\text { m్ } \\
\grave{0} \\
\dot{0} \\
i\end{array}$ & 递 & $\begin{array}{l}\text { oे } \\
\text { o. } \\
\text { i. }\end{array}$ & 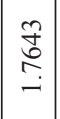 & 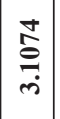 & $\begin{array}{l}\infty \\
\stackrel{T}{0} \\
\stackrel{0}{0}\end{array}$ & 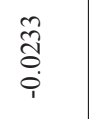 & $\begin{array}{l}\stackrel{0}{0} \\
\dot{0} \\
\dot{\gamma} \\
\dot{\gamma}\end{array}$ & \\
\hline & 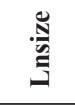 & $\stackrel{\overline{0}}{\stackrel{0}{0}}$ & 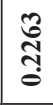 & 音 & 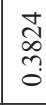 & 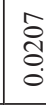 & $\stackrel{5}{8}$ & & $\bar{\alpha}$ & 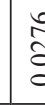 & & & $\begin{array}{l}\infty \\
0 \\
\vdots \\
0 \\
\end{array}$ & & & \begin{tabular}{|l}
0 \\
0 \\
0 \\
0
\end{tabular} & & \begin{tabular}{c}
\multirow{2}{*}{} \\
$\stackrel{0}{0}$ \\
-
\end{tabular} & 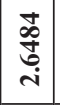 & $\begin{array}{l}\overrightarrow{0} \\
\stackrel{0}{0} \\
0\end{array}$ & 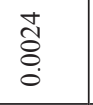 & $\begin{array}{l}\stackrel{0}{2} \\
\vdots \\
\dot{y} \\
\dot{y}\end{array}$ & \\
\hline & 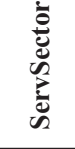 & 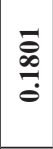 & 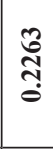 & $\mid \begin{array}{l}\overline{0} \\
\dot{0} \\
0 \\
0\end{array}$ & 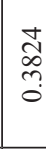 & 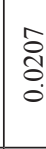 & $\begin{array}{l}\frac{1}{8} \\
\vdots \\
0\end{array}$ & 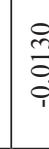 & a & ఏ̊ & & & . & 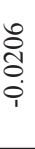 & 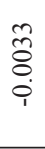 & $\begin{array}{l}0 \\
0 \\
\vdots \\
0 \\
0\end{array}$ & $\begin{array}{l}\text { वे } \\
\text { क्ष } \\
\text { i }\end{array}$ & $\begin{array}{c}\text { fôn } \\
\stackrel{0}{-}\end{array}$ & 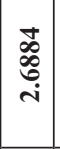 & $\begin{array}{l}\hat{\delta} \\
0 \\
0\end{array}$ & $\begin{array}{l}\overrightarrow{0} \\
\stackrel{0}{\circ} \\
i\end{array}$ & 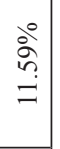 & 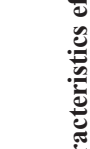 \\
\hline & 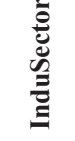 & 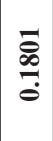 & 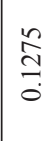 & $\mid \begin{array}{l}\overline{0} \\
\dot{0} \\
0 \\
0\end{array}$ & 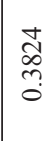 & 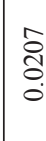 & $\begin{array}{l}\frac{1}{8} \\
\stackrel{8}{0} \\
0\end{array}$ & 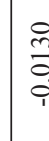 & a & 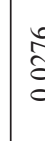 & 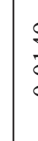 & & 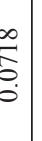 & 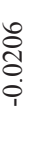 & 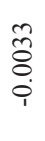 & 递 & $\begin{array}{l}\text { वे } \\
\text { : } \\
\text { î. }\end{array}$ & 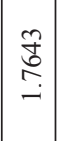 & 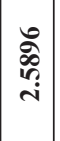 & $\begin{array}{l}\infty \\
\text { ठ } \\
0 \\
0\end{array}$ & 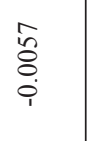 & $\begin{array}{l}\stackrel{\circ}{\circ} \\
\stackrel{0}{\circ} \\
0\end{array}$ & $R$ \\
\hline & $\lambda$ & 芯 & & 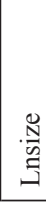 & 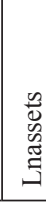 & 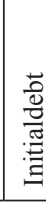 & 量 & 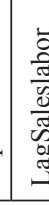 & 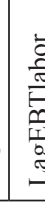 & 1 & & & 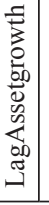 & & 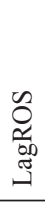 & 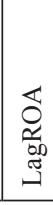 & 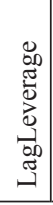 & 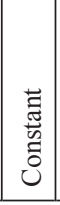 & हू & 12 & & $\begin{array}{c}8 \\
90 \\
0 \\
0 \\
0 \\
0\end{array}$ & $\bar{n}$ \\
\hline
\end{tabular}

